\title{
Um passeio pelos estudos da metáfora
}

Dieysa Fossile ${ }^{1}$

\section{Resumo}

Neste artigo apresento algumas posições concernentes ao percurso que a metáfora traçou ao longo da sua existência, darei atenção (a) à posição de Aristóteles (1996), (b) privilegiarei a versão de Black (1962, 1992, 1993), também incluirei, brevemente, (c) os estudos de Richards (1936) e (d) de Searle (1969, 1993). Neste estudo realizo uma abordagem teórica sobre a metáfora, assunto que faz emergir debates e conflitos de paradigmas.

Palavras-chave: Posições teóricas. Linguagem. Metáfora.

\begin{abstract}
In this article I present some positions about the way that the metaphor traced during its existense, I will give attention to (a) the position of Aristóteles (1996), (b) I will priviledge the version of Black (1962, 1992, 1993), I also will include, shortly, (c) the studies of Richards (1936) and (d) of Searle (1969, 1993). In this study I accomplish a theoric approach about the metaphor, subject that does immerge debates and conflicts of paradigms.
\end{abstract}

Keywords: Theoric Positions. Language. Metaphor.

\section{Introdução}

A metáfora continua sendo alvo de estudos “não” exaustivos. Extremamente complexa e fascinante, a metáfora é objeto de investigação tanto da Linguística, quanto da Filosofia, como também da Psicologia. A Semântica, disciplina do campo da Linguística, tradicionalmente, trata da questão do significado e vem tentado analisar questões relacionadas a essa temática: METÁFORA. Compreender a metáfora não é nada fácil! Várias pesquisas sobre o assunto foram desenvolvidas ao logo da história da Semântica, da Filosofia e da Psicologia e, ainda, continuam sendo desenvolvidas, tal fato faz predominar diferentes posturas metodológicas ao lidar com a explicação sobre o uso metafórico.

Neste artigo, tento apresentar algumas posições no percurso que a metáfora traçou ao longo da sua existência, darei atenção (a) à posição de Aristóteles (1996), (b) privilegiarei a

\footnotetext{
${ }^{1}$ Doutoranda UFSC . Mestre em Lingüística pela Universidade Federal de Santa Catarina, Brasil (2008). E-mail: dieysa@ibest.com.b
} 
versão de Black (1962, 1992, 1993), também incluirei, brevemente, (c) os estudos de Richards (1936) e (d) de Searle (1969, 1993).

Nas seções apresentadas a seguir, abordo que (a) para Aristóteles a metáfora desempenha a função de ornamento. Ele é a favor de que na metáfora um termo (palavra, nome) possa ser trocado/substituído por outro (OLIVEIRA, 1991). Para Searle (1993) há a existência da paráfrase literal da metáfora. (c) Já para Black (1962, 1966, 1993) a metáfora perde a possibilidade de ser parafraseada, ele defende que se uma metáfora for parafraseada literalmente parte do seu valor cognitivo pode ser eliminado/perdido.

\section{A posição tradicional: Aristóteles}

Merece ser discutida, logo no início do passeio pelos estudos da metáfora, a posição de Aristóteles. Pois, Aristóteles, inclui-se entre um dos primeiros que se interessaram em dar uma definição de metáfora. Ele sustentava que a metáfora estava vinculada aos domínios da retórica e da poética. Dessa maneira, é possível, ressaltar que “os primeiros estudos sistemáticos datam do século IV a. C. e foram desenvolvidos pelo grande filósofo estagirita Aristóteles” (COIMBRA, 1999, p. 4). A metáfora, segundo Aristóteles, “[...] consiste no transportar para uma coisa o nome de outra, ou do gênero para a espécie, ou da espécie para o gênero, ou da espécie de uma para a espécie de outra, ou por analogia” (ARISTÓTELES, 1996, cap. XXI, 1457b-6, p. 92).

Essa definição aristotélica pode ser compreendida da seguinte maneira:

A transferência baseada na analogia de quatro termos era considerada a forma mais popular. Dados os termos A está para B tal como C está para D, podemos substituir A por $C$ e vice-versa. Também podemos criar um elo [...] entre A e D ou entre C e B. Por exemplo, se a velhice está para a vida como o entardecer para o dia, podemos falar metaforicamente da velhice do dia e do entardecer da vida (COIMBRA, 1999, p. 4).

A posição de Aristóteles em relação à metáfora foi compreendida como equivalendo à epiphorá do nome, ou seja, à transposição de um nome estranho (allotrios), quer dizer, que designa outra coisa (COIMBRA, 1999, p. 5; RICOEUR, 2005, p. 30 - 32).

A partir daí:

[...] estavam lançadas as bases da hipótese da substituição que via metáfora como um pedido de empréstimo, a um domínio estranho, de um termo que vem ocupar o lugar de um substituens com um significado literal. O mesmo percurso se verificava na comparação que era encarada como uma expansão da metáfora por analogia em 
que o confronto era explicitado por um termo (como, por exemplo) (COIMBRA, 1999, p. 5).

Ricoeur (2005, p. 43-46), por sua vez, argumenta que Aristóteles não tinha como propósito explicar a metáfora pela comparação; mas, sim, o contrário: a comparação pela metáfora. Além disso, o autor esclarece que para Aristóteles o fato do termo de comparação não se fazer presente na metáfora não quer dizer que a metáfora seja uma comparação abreviada, mas se dirá o contrário: a comparação é uma metáfora desenvolvida. Observa-se, então, de acordo com Ricoeur (2005), que toda metáfora seria uma comparação implícita, enquanto que a comparação seria uma metáfora desenvolvida. Já, ao realizar estudos referentes à aproximação da metáfora com a comparação, Aristóteles percebe certa superioridade da metáfora sobre a comparação, pelo fato da metáfora ser entendida e julgada como sendo mais agradável, mais elegante e predicativa ao ser equiparada à comparação.

Então, Ricoeur (p. 47-48), a partir dessa aproximação: metáfora e comparação, defendida por Aristóteles, sugere que a linguagem que é feita de metáforas resulta em um enigma e a essência desse enigma permite falar de coisas reais aproximando termos inconciliáveis, o autor enfatiza que tal coisa não seria possível com a combinação de palavras, apenas com a metáfora.

A definição de metáfora sustentada por Aristóteles, acima apresentada, é discutida por Ricoeur (p. 29) a partir de três traços:

(a) a metáfora é algo que acontece ao nome;

(b) a metáfora é definida em termos de movimento;

(c) a metáfora é a transposição de um nome.

Em outras palavras, a meu ver, para Aristóteles (a) a metáfora está vinculada ao nome e/ou à palavra; (b) a metáfora está vinculada à ideia de movimento, pois conforme os termos gregos metha (que quer dizer "mudança”) e phòra (que significa "levar” ou “conduzir”) a metáfora é uma espécie de mudança e/ou algo que leva/conduz a mudanças, dando a ideia de movimento; (c) a metáfora é a substituição de um termo por outro.

Parece-me, com base nas argumentações de Ricoeur (p. 37), que afirmar que a metáfora é a substituição de um termo por outro, ou melhor, que o termo metafórico é um termo substituto é uma afirmação que traz consequências. Nesse caso, uma das principais consequências seria a seguinte: se a metáfora é a substituição de termos, então a informação fornecida pela metáfora é nula; logo, a metáfora tem apenas valor ornamental e decorativo, 
não servindo para mais nada. A essa altura do passeio já começo a perceber que essa caminhada não será fácil e o “tal” passeio nem tão agradável e, em virtude do afirmado anteriormente, questiono: Poderia a metáfora ser explicada como um simples ornamento e/ou ser a isso reduzida?

Para Aristóteles a metáfora estava vinculada à retórica. Apresento a seguir o modelo aristotélico de postulados implicados em um tratamento puramente retórico da metáfora. Entre esses postulados estão:

Quadro 1 - Modelo aristotélico de postulados

(a) Postulado do próprio e do impróprio ou figurado: este postulado sustenta que a metáfora apresenta os chamados sentidos impróprios ou figurados; enquanto que, dados nomes que pertencem a determinados tipos (gêneros e espécies) de coisas apresentam sentido próprio ou não-figurado.

(b) Postulado da lacuna semântica: é a ausência ou falta de uma palavra no discurso atual.

(c) Postulado do empréstimo: defende que é preciso recorrer ao empréstimo de um termo para preencher a lacuna (cf. postulado (b)).

(d) Postulado do desvio: a metáfora é vista como um desvio em relação ao uso corrente de palavras.

(e) Axioma da substituição: nesse caso, ocorre a substituição de uma palavra por outra no mesmo lugar.

(f) Postulado de caráter paradigmático: entre os termos que se substituem existe uma relação que se pode chamar de razão de transposição, que constitui um paradigma.

(g) Postulado da paráfrase exaustiva: encontrar um termo apropriado para substituir de maneira exaustiva o termo impróprio.

(h) Postulado de informação nula: Se se pode confirmar o postulado (g) - a metáfora não ensina nada. Fonte: Ricoeur (2005, p. 79-81)

Através do modelo aristotélico apresentado, principalmente a partir dos dois últimos postulados do modelo, parece-me que se a metáfora não ensina nada, ela desempenha, de acordo com a posição aristotélica, uma só função: ornar a linguagem, dando, segundo Ricoeur (2005, p. 81), “[...] cor ao discurso [e] uma vestimenta à expressão nua do pensamento”. Richards (1936), por exemplo, afirma que, a princípio, na história da retórica a metáfora foi compreendida como um ornamento, como uma graça. É importante retomar a afirmação anteriormente citada e, novamente, ressaltar que Giambatista Vico foi um dos primeiros a notar que a noção de Aristóteles de considerar a metáfora o mais importante adorno literário pode ser um engano. Vico afirmou que “[...] a poesia e a linguagem são essencialmente idênticas e que a metáfora [está] longe de ser um recurso literário, [pois] constitui o corpo principal de todas as línguas” (SÁBATO, 1982, p. 117). Tanto Vico no século XVII quanto Rousseau no século XVIII impulsionaram a ideia de que “[...] a metáfora desempenhava um papel importante [...] [na] época [da origem] da linguagem” (CAMBRUSSI E MOURA, 2008, p. 18). 
Segundo Rousseau (1987), o homem começou a desenvolver a linguagem verbal, exprimindo suas emoções. Desse modo, Rousseau apresentou “[...] a hipótese, que outros autores também defenderam [...] de que as primeiras palavras proferidas pelos seres humanos seriam metafóricas” (CAMBRUSSI E MOURA, 2008, p. 18). Embora existam várias controvérsias e polêmicas em relação à teoria de Aristóteles, é notável que a teoria aristotélica da metáfora como figura retórica que desempenhava, essencialmente, a função de ornar, predominou com vigor durante 23 séculos. E, atualmente, a maioria das pessoas continua compreendendo a metáfora dessa maneira (ZANOTTO, 1995; ZANOTTO E PALMA, 1998). Finalizo, portanto, esta seção, argumentando que Aristóteles considerou a metáfora “[...] como a arte de persuadir e [a] arte de ornamentar. Dessa maneira, na sua visão, a metáfora pertence [...] ao domínio da retórica, arte da persuasão” (BOAS, 2010, p. 35-36).

Na próxima seção, abordarei a perspectiva de Richards (1936), com o objetivo de verificar se sua investigação se assemelha ou se diferencia da visão aristotélica.

\section{Uma tentativa para sair do tradicional: I. A. Richards}

I. A. Richards (1936) também foi um autor fundamental nas pesquisas desenvolvidas sobre a metáfora. Ele desenvolveu seus estudos no século XX, por volta da década de 30. Os estudos de Richards seguem a linha de investigação literária. Esse autor também vinculou a teoria da metáfora à retórica, porém a sua versão se distingue da aristotélica. É importante esclarecer que a retórica antiga e clássica de Aristóteles limitava-se a descrever os ornamentos da linguagem, no caso: “a metáfora”. E o que a retórica denominou de metáfora estava ancorado na mudança de sentido da palavra, ou seja, a definição da metáfora estava centrada na ideia da transposição de um nome ou de uma palavra estranhos à outra coisa. Assim, a definição de Aristóteles à metáfora era nominal. Porém, Richards assumiu uma nova definição de retórica. Para ele a retórica não se preocupava apenas com a descrição ornamental da linguagem, mas passou a ser vista como uma disciplina filosófica que visava alcançar o domínio das leis fundamentais do uso da linguagem (RICHARDS, 1936; RICOEUR, 2005, p. 123). O autor defendeu que a retórica seria a teoria do discurso, do pensamento como discurso. Ele a situou no plano verbal. Logo, essa nova definição de retórica influenciou sobre a visão da metáfora. Além disso, por meio dessa nova definição Richards rompeu com a teoria da palavra, a qual era seguida por Aristóteles. Para Richards o sentido de uma frase não deriva do sentido das palavras, mas acontece como algo que envolve 
a semântica da frase toda. Essa noção contribuiu para que o autor pudesse tornar “[...] pública a teoria da interpenetração das partes do discurso sobre a qual edificará a teoria da interação própria à metáfora” (RICOEUR, 2005, p. 126).

Por meio da sua Teoria da Interação, Richards sustentava que a metáfora conserva dois pensamentos diferentes ao mesmo tempo, resultando, desse modo, uma significação da interação desses dois pensamentos. "Para ele, a linguagem em si mesma, com seu arsenal de itens lexicais e relações semânticas entre eles, não permite definir a forma que a metáfora assumirá: a metáfora nasce no uso. E esse uso é regido pelo pensamento. A metáfora é um instrumento do pensamento” (MOURA, 2008, p. 182). O autor defende que a metáfora não é um simples deslocamento de palavras, mas um comércio de pensamentos, ou seja, uma transação entre contextos. Para ele a metáfora é um talento do pensamento (RICOEUR, 2005, p. 129). Foi ele também quem introduziu o caráter binário da metáfora. Dividiu o enunciado metafórico em (a) conteúdo (tenor) e (b) veículo (vehicle). O conteúdo e o veículo “[...] não correspondem a palavras, mas a pensamentos [...] [nesse caso] a matéria prima da metáfora são conceitos, e não palavras” (MOURA, 2008, p. 182). O autor também enfatiza que não se pode “[...] falar do conteúdo fora da figura, ou tratar o veículo como um ornamento sobreposto: é a presença simultânea do conteúdo e do veículo e sua interação que dão origem à metáfora; desde então o conteúdo não permanece imutável, como se o veículo fosse apenas uma vestimenta, um ornamento” (RICOEUR, 2005, p. 130).

Dessa maneira, já começo a responder o questionamento lançado na seção precedente (Poderia a metáfora ser explicada como um simples ornamento e/ou ser a isso reduzida?), percebendo que a teoria da retórica seguida por Aristóteles que se limitava a descrever os ornamentos da linguagem é criticada por tão somente tratar de questões superficiais. E com Richards já é possível verificar que a metáfora não se reduz a simples ornamento e, sim, diz respeito à própria interação verbal. Parece-me que a própria definição de retórica adotada por Richards, conforme apresentado acima (RICHARDS, 1965, p. 23), contribuiu para que a metáfora fosse compreendida como uma interação verbal e não como ornamento da linguagem. A meu ver, um dos fatos mais notáveis do estudo desenvolvido por Richards foi a percepção de que a metáfora não era apenas a troca ou substituição ou deslocamento de palavras, mas a interação de pensamentos. E, parece-me, que esse fato contribuiu para conduzir a investigação de Richards à percepção de que a metáfora era composta por conceitos e não apenas por palavras.

Foi a partir dos estudos de Richards que a dicotomia: linguagem vs. pensamento foi impulsionada. Nessa dicotomia o pensamento era enfatizado. E é dessa maneira que se inicia 
“[...] uma longa tradição que separa dois planos na metáfora: o plano conceptual (que relaciona conceitos) e o plano da expressão (as palavras que são usadas para exprimir esses conceitos)” (MOURA, 2008, p. 182).

Mais tarde houve uma fusão entre a linha de investigação literária, que era seguida por Richards, com o campo da filosofia analítica. O principal representante que realizou, a princípio, a fusão entre essas áreas de estudos teóricos foi Max Black, porém foram os estudos de Richards que abriram caminho para que outros estudiosos sobre o assunto, tal como Black, pudessem desenvolver suas investigações. Portanto, finalizo esta seção concluindo que, conforme discutido, Richards investiu na questão da atividade simultânea de dois pensamentos, ou seja, sugeriu que o leitor de uma metáfora, ao interpretá-la, é conduzido a ligar duas ideias.

\section{Teoria da Interação Semântica: Max Black}

Black foi o autor do famoso texto: "Metaphor” (1962) que se tornou um clássico para o assunto sobre metáforas. Esse autor sintetiza de maneira central as teses principais de uma análise semântica da metáfora que se fixa no nível do enunciado em seu todo, para dar conta de uma mudança de sentido que se estabelece na palavra (RICOEUR, 2005, p. 134). Black passa a compreender a metáfora não mais como um mecanismo puramente linguístico, ele tenta mostrar que a metáfora é um modo diferente de organizar a realidade, sendo, portanto, um processo cognitivo. Esse autor em seu texto “More about Metaphor” (1993) esclarece que sua meta principal por meio desse texto é ampliar e rever sua formulação original abordada em “Metaphor”, portanto, tenta na sua recaptulação, explicar/discutir as principais questões que norteiam o funcionamento da metáfora. Ele defende que o significado de uma metáfora interessante é tipicamente “novo” e “criativo”. Black (1993, p. 24) sustenta que uma mesma declaração metafórica pode receber um número de diferentes e conflitantes leituras. Aborda que o significado de uma metáfora pode ser plausível para um leitor e não plausível para outro. A partir daí, Black objetiva abordar que há uma inescapável indeterminação na interpretação da metáfora. Nesse caso, uma metáfora pode ter um sentido para uma pessoa e outro sentido para outra pessoa. Com isso um novo questionamento começa a me deixar um tanto intrigada e preocupada: Então, quer dizer que uma metáfora pode ter mais de um sentido e não apenas um único? Cada pessoa pode interpretar a metáfora do seu jeito? 
Mesmo que as dúvidas se tornem obstáculos pelo caminho, continuarei com a investigação para ver se alcanço algum esclarecimento coerente no decorrer da caminhada. De acordo com o que já apresentei na seção anterior, foram as ideias valiosas de Richards que contribuíram para a formulação da Teoria da Interação Semântica de Max Black. Black rejeita a visão da Substituição e da Comparação. A visão da Substituição considera que uma sentença metafórica inteira possa substituir uma sentença literal. Já a visão da Comparação conduz muitas metáforas à ideia de símile elíptico. O autor (p. 27) discute algumas questões relacionadas à sua perspectiva interacionista e ao seu texto "Metaphor" (1962) e tenta esclarecer algumas questões sobre o funcionamento da metáfora, entre elas:

(a) ressalta que uma declaração metafórica tem dois temas que podem ser identificados como: (a) tema primário e (b) tema secundário. Essa dualidade é marcada pelo contraste entre o focus da declaração metafórica (que é a palavra que é usada metaforicamente) e frame (que é o restante da frase que é usado literalmente). Por exemplo: “A mulher é uma rosa”, de acordo com Black, a metáfora não está centrada apenas na palavra rosa, mas está no relacionamento que os elementos de um enunciado estabelecem entre si. Dessa forma, entende-se que há uma inter-relação entre o focus $\rightarrow$ (elemento metafórico: uma rosa), embutido no frame $\rightarrow$ (estrutura gramatical não-metafórica: “A mulher é ”). A partir da ideia esboçada por Black, parece-me que o focus é tido como um elemento metafórico, o qual faz parte de uma estrutura não-metafórica (frame) e a interação é o resultado da "relação" que ocorre entre o focus e o frame, por isso o nome de Teoria Interacionista (OLIVEIRA, 1991).

(b) Black (1993, p. 28) argumenta que um enunciado metafórico funciona projetando sobre o tema primário um conjunto de implicações associadas, as quais são predicáveis do tema secundário. Dessa maneira, a ideia de significado em Black está ligada à noção de sistema de lugares comuns associados, o que Aristóteles, por sua vez, chamou de endoxa (conjunto de opiniões compartilhadas pelos membros de certa comunidade de falantes). Por exemplo, o termo rosa, presente na frase acima mencionada, evoca um sistema de lugares comuns associados, trazendo à mente conceitos como:

- bonita, cheirosa, delicada. Esses traços associados à rosa são projetados sobre o conceito de mulher. Ou seja, aplicamos os atributos (estereótipos ou conotações) triviais de rosa à mulher. 
Nesse caso, parece-me que a pretensão de Black é, justamente, tentar mostrar que as convenções de conotação estão associadas a uma palavra. E tomando como base o exemplo citado, percebo que a palavra "rosa” evoca um "sistema de lugares comuns associados" e acaba organizando a nossa visão de mulher. Isso significa que podemos alcançar o sentido de uma sentença metafórica por meio das conotações de uma palavra que a constitui. Além das conotações, o conhecimento e o uso da linguagem também podem auxiliar na busca do sentido metafórico de uma dada sentença (OLIVEIRA, 1991).

Logo, se as conotações têm caráter convencional em uma comunidade linguística, isso significa que as metáforas, talvez, também tenham uma interpretação definida. Isso quer dizer que o conhecimento dos usos convencionais de uma palavra que compõe uma metáfora admite que se busque e se alcance o sentido metafórico de um novo uso. A partir dessa noção blackiana de "sistema de lugares comuns associados", parece-me que teríamos aí imbricadas duas questões, uma de certa maneira positiva e, outra, negativa, respectivamente: (a) a metáfora teria um e somente um sentido; (b) buscar o sentido da metáfora através das conotações acaba limitando o verdadeiro significado que a metáfora tem, ou seja, o seu valor cognitivo.

(c) Black supõe que um enunciado metafórico não pode ser representado por qualquer paráfrase. O autor sustenta que arriscar traduções literais leva a eliminar o valor cognitivo da metáfora, (foi o que notei acima, por isso apresentei a "questão negativa" que nortearia a noção de sistema de lugares comuns associados).

(d) segundo Black, no contexto de uma declaração metafórica, os dois temas interagem da seguinte maneira: (d1) a presença do tema primário incita/instiga o ouvinte a selecionar algumas propriedades para serem aplicadas ao tema secundário; (d2) convida o ouvinte a construir um paralelo de implicações complexas que podem preencher um tema primário; (d3) reciprocamente induz mudanças paralelas no tema secundário. Black julga que essa interação pode ser considerada o “xis” da questão (fato que lembra também a tentativa de Richards ao buscar uma explicação e abordá-la por meio da questão da “interanimação” das palavras). O autor relata que a interação dos temas produz um resultado nas mentes do falante e ouvinte.

Black orienta que nós devemos necessariamente ler "atrás das palavras”. Ele também afirma que a ambiguidade é necessariamente um produto da metáfora. A meu ver, essa afirmação sobre a ambiguidade metafórica reforça a ideia de que a metáfora é um caso de 
indeterminação. Black deixa claro que o produtor de uma metáfora não está simplesmente comparando A com B, nem mesmo pensando em A como se fosse B; mas, sim, ele produz um “flash of insight” ao perceber A e B. A partir daí, o autor volta a abordar que uma mesma metáfora pode ser entendida de várias maneiras e compara-a com uma figura geométrica, mais precisamente, com a "Estrela de Davi”. Com base na estrela, tenta mostrar que há várias formas de se ver um mesmo objeto. Ao discutir essa questão, Black ressalta um questionamento bem interessante: Por que tentar ver A como metaforicamente B, quando A não é literalmente B? O autor apresenta a seguinte resposta ao questionamento: Tentamos ver A como metaforicamente $B$, porque criamos limites conceituais que não são rígidos, mas são elásticos (BLACK, 1993, p. 33).

Black ressalta que não há um teste infalível para discriminar o metafórico do literal, assim como não há nenhum teste para resolver a questão da ambiguidade. $\mathrm{O}$ autor em seu texto "More about Metaphor" também discute a questão da criatividade das metáforas. Ao abordar esse ponto, ele sustenta que uma declaração metafórica pode determinadas vezes gerar um novo insight e um conhecimento que são derivados das relações entre o tema primário e o secundário. O autor advoga que estar de acordo com essa posição é atribuir uma forte função cognitiva a certas metáforas. Em virtude disso, Black advoga que as metáforas podem gerar insights de “como as coisas são” na realidade.

Black em seu texto "Modelos y metáforas" (de 1966) também sustentou que a metáfora tinha um caráter cognitivo, sendo, dessa forma, entendida como um instrumento que ajudaria a ver novos aspectos da realidade, os quais ela mesma criaria. Então a metáfora passou a ser considerada como CRIADORA. Portanto, para Black a questão central é que a metáfora cria algo novo, isto é, as metáforas são criadoras de novas associações.

\section{Teoria metáforica: John Searle}

John Searle (1993) em seu texto “Metaphor” apresenta uma teoria da metáfora em que toma como foco central a distinção entre Significado da Sentença (SS) e Significado do Falante (SF) (FINGER, 1996; FOSSILE, 2008a, 2008b, 2008c, 2009; MOURA, 2002, 2005, 2006, 2007, 2008; ZANOTTO e MOURA, 2009). Searle é a favor dos que argumentam que o significado literal da sentença não é metafórico, pois para ele a metaforicidade está, na maioria das vezes, no significado do falante. Essa noção o diferencia dos autores que buscam localizar o elemento metafórico no enunciado expresso pela sentença. 
Esse autor elabora a sua teoria da metáfora, partindo da análise das perspectivas já existentes, mostrando sua insatisfação com determinadas versões como a Teoria da Comparação e a Teoria da Interação Semântica (sobre essas teorias conferir seções precedentes). Pois, para Searle o significado metafórico é diferente do significado da sentença. Segundo o autor, quando um falante opta por utilizar uma sentença metaforicamente, ao invés de usá-la literalmente, ele está desejando mostrar sua intenção de comunicar alguma coisa diferente; logo, segundo o autor, não há equivalência entre o significado do falante e o significado da sentenȩa ("SF \# SS"). A partir daí, objetiva defender que o significado da palavra, ou então, da sentença NUNCA é metafórico, já o significado do falante ou do proferimento poderá ser tido como metafórico, em alguns casos.

O significado da metáfora nas teorias da Comparação e da Interação Semântica é dado pela (a) comparação (semelhança, similaridade) entre termos que constituem uma sentença e pela (b) interação entre palavras que compõe uma sentença, respectivamente. Portanto, de acordo com essas teorias, o significado metafórico está localizado na sentença, alternativa que é refutada por Searle. O autor advoga, como se vê acima, que a sentença NUNCA será metafórica. Ele afirma que na teoria interacionista não há qualquer tipo de interação entre focus e frame e que essa teoria em nada contribui para explicar a metáfora. Conforme abordado, para Searle o enunciado metafórico NÃO modifica o significado das palavras, ele sustenta que elas mantêm o seu sentido literal. Mas o autor enfatiza que alguma mudança é causada a partir da intenção que o falante institui à frase. Essa sua suposição pode ser averiguada na seguinte passagem: "Metaphorical meaning is always speacher's utterance meaning" (SEARLE, 1993, p. 84).

Searle acredita que uma das questões problemáticas de algumas teorias que estudam e analisam metáforas é que o que dizem sobre as metáforas também acaba valendo para os proferimentos literais. A partir daí, sua preocupação consiste em formular uma teoria que seja capaz de diferenciar proferimentos metafóricos de literais. Então, com base nessa preocupação, realiza uma abordagem sobre:

(a) Proferimentos literais:

[...] quando a comunicação envolve o emprego de proferimentos literais e o falante diz S é P pretendendo significar nada além de S é P, para Searle, o que ocorre é que o falante situa o objeto $\mathrm{S}$ dentro da classe definida pelo conceito $\mathrm{P}$ e, nesse caso, o significado da sentença e o significado do proferimento são exatamente o mesmo. Para que o ouvinte seja capaz de compreender o que realmente está sendo comunicado, faz-se necessário que ele conheça as regras da linguagem, perceba em 
que condições o enunciado está sendo utilizado e possua um conjunto de suposições de background que sejam comuns a ele e ao falante (FINGER, 1996, p. 52).

(b) Proferimentos NÃO-literais: Searle propõe que há três princípios envolvidos numa situação em que um falante enuncia S é $\mathrm{P}$, querendo dizer, metaforicamente $\mathrm{S}$ é $\mathrm{R}$, em que R distingue de P. Para Searle, esses três princípios são “individualmente necessários e coletivamente suficientes” (Ibid., p. 53) - (“[...] individually necessary and collectively suficient” (SEARLE, 1991, p. 536 apud FINGER, 1996, p. 53)) - para que tanto os falantes quanto os ouvintes possam compreender os proferimentos metafóricos:

Quadro 2 - Três Princípios de Searle

\begin{tabular}{|c|c|}
\hline $1^{\circ}$ Princípio & $\begin{array}{l}\text { "Tanto falante como ouvinte devem possuir algumas estratégias que sejam comuns a } \\
\text { ambos para que sejam capazes de criar e reconhecer proferimentos que tenham tido } \\
\text { ou não a intenção de ser literais” (FINGER, 1996, p. 53). Por exemplo, devem } \\
\text { detectar que o enunciado metafórico é problemático se tomado de forma literal. Por } \\
\text { exemplo: Carla (S) é uma cobra (P) (sentença problemática); portanto, Carla (S) NÃO } \\
\text { pode ser uma cobra (P) (OLIVEIRA, 1991, p. 18). }\end{array}$ \\
\hline $2^{0}$ Princípio & $\begin{array}{l}\text { Ambos interlocutores devem partilhar princípios que os } \\
\text { habilitem a computar valores possíveis de } R \text { e associar o } \\
\text { termo } P \text { a esse conjunto. Durante a troca comunicativa, é } \\
\text { nesse momento que o ouvinte, com base em seu } \\
\text { conhecimento do mundo, extrai do termo } P \text { aspectos } \\
\text { salientes, bem-conhecidos ou característicos que possam } \\
\text { fornecer todos os valores possíveis de } R \text { (FINGER, } \\
\text { 1996, p. 53). }\end{array}$ \\
\hline $3^{\circ}$ Princípio & 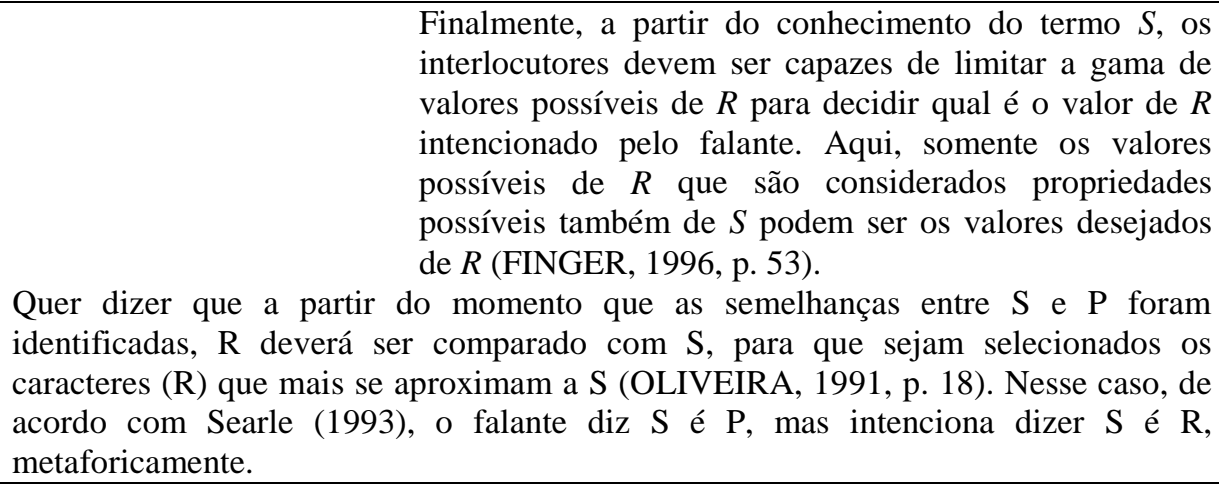 \\
\hline
\end{tabular}

Fonte: Searle (1993)

Uma outra questão discutida por Searle e, que é alvo de grande discussão, é a questão da paráfrase literal da metáfora. Para Searle, pode resultar paráfrase literal em casos em que um 
proferimento metafórico de um enunciado como $S$ é $P$ identifica num outro enunciado do tipo $S$ é $R$ as mesmas condições de verdade (OLIVEIRA, 1991).

\section{Uma opção teórica e considerações finais}

Conforme se pôde acompanhar, o passeio pelos estudos e/ou pelas teorias metafóricas foi, julgo, produtivo, pois pude retomar e, mais uma vez, avaliar algumas perspectivas teóricas existentes e tentar a partir desse passeio me posicionar a favor de uma teoria e, desse modo, refutar outras. O passeio se deu por teorias em que a abordagem sobre a metáfora se centrou no nível linguístico, no nível pragmático e no nível linguístico-cognitivo.

A partir deste passeio analítico pelas teorias metafóricas, refuto, neste estudo, a teoria aristotélica e a teoria de caráter puramente pragmático (Teoria de Searle). Assumo, portanto, a Teoria da Interação Semântica de Black que leva em consideração tanto o nível linguístico quanto o cognitivo, embora existam, nessa teoria, algumas questões dificultosas que carecem de explicação $\rightarrow$ sobre a indeterminação da metáfora e o sistema de implicações associadas (porém essas questões não serão abordadas neste momento devido à amplitude da discussão).

Pois, a partir do levantamento teórico realizado, a teoria de Aristóteles não me parece plausível, a metáfora não pode simplesmente desempenhar a função de ornar a linguagem, sendo desprovida de todo e qualquer valor cognitivo. Nem mesmo me parece condizente a proposta de Searle de que a metáfora pode ser compreendida como um tipo de ato de fala indireto, em que a intenção do falante ultrapassa o significado da sentença e, em dados momentos, nem coincide com ela. Além disso, a afirmação de Searle de que o significado da sentença NUNCA será metafórico também me parece um tanto problemática. Pois, isso quer dizer que a ideia de que a metáfora possa estar/atuar na forma do enunciado é, totalmente, abandonada. Portanto, discordo que a metáfora seja somente um ornamento da linguagem, de troca e substituição de palavras, ou então, um fenômeno exclusivamente cognitivo, ou, apenas, fruto da intenção do falante. Não pode ser possível que o significado das palavras e/ou das sentenças não esteja envolvido com a questão da metáfora tal como pretendem as versões pragmática e cognitiva. Nem mesmo que a metáfora seja desprovida de conteúdo cognitivo como quer a perspectiva de Aristóteles. É por isso que dentre as teorias apresentadas julgo que a perspectiva Interacionista seja uma alternativa eficiente para explicar o fenômeno da metáfora, já que considera que tanto fatores cognitivos quanto fatores linguísticos estão envolvidos, no que diz respeito, ao fenômeno metafórico, enfatizando que a metáfora é um 
fenômeno especial em que os termos que compõem o enunciado interagem, simultaneamente, gerando uma operação mental, dando a entender que a linguagem CRIA/GERA realidades e organizações do pensar. Com a versão interacionista, a metáfora passa a ser vista como um fenômeno capaz de CRIAR conhecimento, essa, talvez, tenha sido uma das sacadas mais brilhantes de Black (cf. OLIVEIRA, 1991). Isto é, conforme Moura e Pereira (2008, p. 02)

\begin{abstract}
[...] a linha interacionista [...] não vê a metáfora como uma mudança de significado apenas, isto é, uma superposição de uma acepção nova à acepção antiga da palavra, mas afirma que há uma interação entre o tópico e o veículo do enunciado metafórico, por isso, não há uma substituição de significados, porém um ponto de intersecção entre os significados do tópico e do enunciado metafórico.
\end{abstract}

\title{
Referências
}

ARISTÓTELES. Poética. Tradução: SOUZA, E. de. Porto Alegre: Globo, 1996.

BLACK, M. Metaphor. In: Models and metaphor. Ithaca: Cornell University Press, cap. 3, 1962.

. Como as metáforas funcionam: uma resposta a D. Davidson. In: SACKS, Sheldon

(Org.). Da metáfora. São Paulo: Educ, 1992.

More about metaphor. In: ORTONY, A. (Ed.). Metaphor and thought. Cambridge:

Cambridge University Press, 1993.

. Modelos y metáforas. Madrid: Tecnos, 1966. p. 205-238.

BOAS, G. A. de V. Metáforas conceptuais de tempo, vida e morte na construção colaborativa das leituras de um texto literário. 2010. 127 f. Dissertação (Mestrado em Linguística Aplicada e Estudos da Linguagem) - Curso de Pós-Graduação em Linguística Aplicada e Estudos da Linguagem, Pontifícia Universidade Católica de São Paulo, São Paulo, 2010.

COIMBRA, R. L. A linguagem metafórica. 1999. Tese (Doutorado em Letras/Linguística) Curso de Pós-Graduação em Letras/Linguística, Universidade de Aveiro, Aveiro, 1999.

FINGER, I. Metáfora e significação. Porto Alegre: EDIPUCRS, 1996.

FOSSILE, D. K. Interpretação de metáforas com verbos de mudança de estado. Revista

Ciências e Cognição. Rio de Janeiro, v. 13, n. 3, p. 187-198, 2008 a.

. Regularidade Interpretativa nas metáforas com verbos de mudança de estado. Revista

Línguas e Letras, Cascavel, v. 9, n. 16, p. 37-66, 2008b.

Semântica \& Pragmática: campos in/dependentes. Revista Polidiscidinar Eletrônica

da Faculdade de Guaicará, Guarapuava, v. 1, n. 2, p. 40-58, 2009. 
Metáforas com verbos de mudança de estado. 2008. 90 f. Dissertação (Mestrado em Letras/Linguística) - Curso de Pós-Graduação em Letras/Linguística, Universidade Federal de Santa Catarina, Florianópolis, 2008c.

MOURA, H. M. M. Metáfora: das palavras aos conceitos. Letras de Hoje, Porto Alegre, v. 40, n. 139, p. 51-69, 2005.

.Linguagem e cognição na interpretação de metáforas. Revista Veredas, 6-1, 2002, p. 153-161.

The conceptual and the linguistic factors in the use of metaphors. DELTA. São Paulo, v. 22, n. especial, p. 81-94, 2006.

Relações paradigmáticas e sintagmáticas na interpretação de metáforas. Linguagem e (dis)curso, Tubarão, v. 7, n. 3, p. 417-452, 2007.

Desfazendo dicotomias em trono da metáfora. Revista de estudos da linguagem. Belo Horizonte, v. 16, n. 1, p. 179 - 200, 2008.

e CAMBRUSSI, M. F. História dos estudos linguísticos. Florianópolis: UFSC, 2008.

e PEREIRA, I. Máquinas e mentes: interpretando a metáfora. Working papers

lingüística, Florianópolis, v. 9, n. 1, p. 81-99, jan.-jun. de 2008.

OLIVEIRA, R. P. As faces do rosto. 1991. 119 f. Dissertação (Mestrado em

Letras/Linguística) - Curso de Pós-Graduação em Letras/Linguística, Universidade Estadual de Campinas, Campinas, 1991.

RICOUER, P. A metáfora viva. São Paulo: Loyola, 2005.

RICHARDS, I. A. The philosophy of rhetoric. Oxford: Oxford University Press, 1936.

ROUSSEAU, J. J. Ensaio sobre a origem das línguas.. São Paulo: Nova Cultural, 1987. (Coleção Os pensadores).

SEARLE, J. Metaphor. In: ORTONY, A. (Ed.). Metaphor and Thought. 2. ed. Cambridge: Cambridge University, 1993. p. 83-111.

ZANOTTO, M. S.; MOURA, H. Investigando teórica e empiricamente a indeterminação da metáfora. Revista Gragoatá, Niterói, n. 26, p. 9-42, 2009.

ZANOTTO, M. S. Metáfora, Cognição e Ensino de Leitura. DELTA. Documentação de Estudos em Linguística Teórica e Aplicada, Sao Paulo, v. 11, n. 2, p. 241-254, 1995.

ZANOTTO, M. S.; PALMA, D. V. Metáfora, Cognição e Ensino de Leitura: O Pensar Metafórico em Sala de Aula. In: BASTOS, Neusa Barbosa (Organizadora). (Org.). Língua Portuguesa: Histórias, Perspectivas, Ensino. São Paulo: EDUC, 1998. 